\title{
Phosphate and potassium solubilizing bacteria from weathered materials of denatured rock mountain, Ha Tien, Kiên Giang province, Vietnam
}

\author{
Cao Ngoc Diep ${ }^{1,2, *}$, Than Ngoc Hieu ${ }^{1,2, *}$ \\ ${ }^{1}$ Dept. Microbiology Biotechnology, Depertment of Rural Development, Can Tho City, Vietnam \\ ${ }^{2}$ Agriculture and Rural Development Dept., Biotechnology R\&D Institute, Can Tho University, Can Tho City, Vietnam
}

\section{Email address:}

cndiep@ctu.edu.vn(C. N. Diep), thanngochieu@gmail.com(T. N. Hieu)

To cite this article:

Cao Ngoc Diep, Than Ngoc Hieu. Phosphate and Potassium Solubilizing Bacteria from Weathered Materials of denatured Rock Mountain, Ha Tien, Kien Giang Province, Vietnam. American Journal of Life Sciences. Vol. 1, No. 3, 2013, pp. 88-92.

doi: 10.11648/j.ajls.20130103.12

\begin{abstract}
Twenty-five strains were isolated on Aleksandrov medium from sample soils/weathered rocks of Ha Tien Mountain, Kien Giang, Vietnam. Their colonies were round or irregular, white to yellow and their shape was rod, motile. Seventeen of twenty-five bacterial strains were identified by PCR technique with specific primers fd 1 and $\mathrm{rP}$, they were capable of dissolving both phosphate and potassium and seven strains had high phosphate and potassium dissolution capacity $\left(>10 \mathrm{mg} \mathrm{l}^{-1} \mathrm{P}_{2} \mathrm{O}_{5}\right.$ and $>50 \mathrm{mg} \mathrm{l}^{-1} \mathrm{~K}_{2} \mathrm{O}$ ) effectively. These seven strains were chosen to sequence, DNA sequencing were compared with GenBank database of NCBI by BLAST N software. The results showed that DNV16 strain was similarity of 99\% with EU977655.1 (Microbacterium hominis), TC1D strain was a 99\% similarity with FN547417.1 (Flectobacillus sp.), CH9E strain was a 99\% similarity of 99\% with GQ861463.1 (Agrobacterium tumefasciens), TC1A strain was similarity of 99\% with HM003210.1 (Bacillus cereus) and FJ976533.1 (Bacillus coagulans), CH7A strain was 99\% similarity with EU048539.1 (Bacillus cereus) and GQ214131.1 (Bacillus subtilis) and TD6B strain was a 99\% similarity wih AB301013.1 (Bacillus subtilis) and CH7D strain was similarity of 98\% with FJ976616.1 (Bacillus megaterium). Seven strains related with Bacillus megaterium and Bacillus coagulans closely in phylogenetic tree.
\end{abstract}

Keywords: Bacillus Coagulans, Bacillus Megaterium, Denatured Rock, Identification, Phosphate and Potassium Solubilization

\section{Introduction}

Phosphate $(\mathrm{P})$ and potassium $(\mathrm{K})$ are the major essential macronitrients for biological growth and development. However, the concentration of soluble $\mathrm{P}$ and $\mathrm{K}$ in soil are usually very low, and the biggest proportion of $\mathrm{P}$ and $\mathrm{K}$ in soil are insoluble rocks, minerals and deposits[1]. The weathering of rocks plays a role in a number of important environmental processes[2] to clay, silt and sand and these minerals are important component of soil in earth. In spite of that, these sources constitute the biggest reservoirs of $\mathrm{P}$ and $\mathrm{K}$ in soil because, under appropriate conditions, they can be solubilized and become available for plants[3]. The Mekong Delta occupies 2.9 million ha $(12 \%$ of the Vietnam's total land area) and is one of the two principal areas of rice production of Vietnam. About $35 \%$ of the Mekong Delta is alluvial soil, covering 1.1 million ha along the rivers with most of the remainder acid sulfate clay soil (1.6 million ha). Both the acid and alluvial soils are deficient in phosphorus since $\mathrm{P}$ generally reacts with aluminium and iron under low $\mathrm{pH}$ conditions and forms insoluble compounds[4]. Besides that, $\mathrm{K}$ is also an important macronutrient for plant growth but potassium fertilizer, as potassium chloride, has been imported with big quantity every year because Vietnam has no mineral resource to produce potassium fertilizer. However, K fertilizer cost has not to stop enhance every year, this has led to increase cost of rice production and farmer's income should reduce.

Microorganisms play a central role in the natural $\mathrm{P}$ and $\mathrm{K}$ cycle and $\mathrm{P}$ - or K-solubilizing bacteria in soil and in plant rhizospheres[5]; there are bacteria species having high ability to solubilize inorganic phosphate compounds[6] and silicate bacteria were found to resolve potassium, silicon and aluminum from insoluble minerals[7]. Recently 
Xiufang et al.[3] found the community of microorganisms in soil of Tianmu Mountain, Zhejiang, China with herbal plants flourished and they were able to dissolve both $\mathrm{P}$ - and K-containing minerals. The aims of this study were (i) selection and (ii) identification the isolated $\mathrm{P}$ - and K-solubilizing bacteria from soil of denatured mountains of Ha Tien town, Kien Giang province, Vietnam.

\section{Material and Methods}

\subsection{Bacteria Isolation and Growth Conditions}

Bacterial stains were isolated from Ha Tien Mountain, Kien Giang Province, Vietnam (Figure 1), by virtue of their abilities to solubilize mineral $\mathrm{P}$ - and $\mathrm{K}$. The samples were stored at $10^{\circ} \mathrm{C}$ during transit and processed immediately.

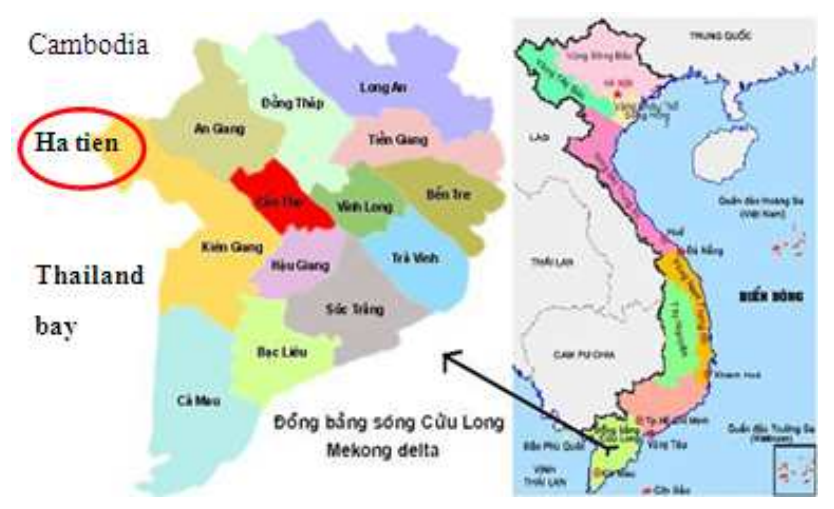

Figure 1. Location of Ha Tien, Kien Giang, Vietnam examined in this study (nearby Thailand Bay)

Soil samples or weathering materials were collected from the areas where herbal plants flourished (Figure 2). Each sample $(2 \mathrm{~g})$ was added to $25 \mathrm{ml}$ of liquid Aleksandrov medium[3] with $0.2 \%$ apatite and $0.2 \%$ kaolinite and shaken for $24 \mathrm{~h}$ on orbital shaker at $50 \mathrm{rev}$ min-1 at temperature room.

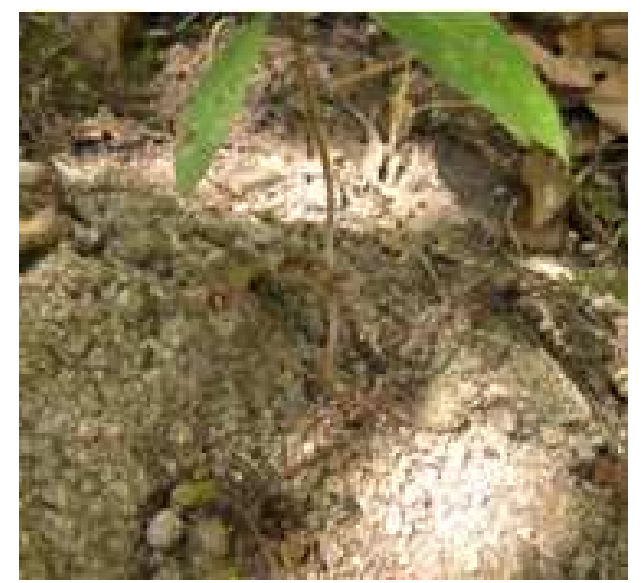

Figure 2. Soil samples or weathering materials were collected to isolate bacteria

A 10-fold dilution series were made. Dilution were plated onto the same medium and incubated at $30^{\circ} \mathrm{C}$ for 24 h. The colonies on the $10^{-6}$ dilution plate were picked and grown in the same liquid medium, and then colonies were selected from plates and they were separate isolates, stored at medium agar tubes at $4^{\circ} \mathrm{C}$ and medium glycerol at $20^{\circ} \mathrm{C}$.

\subsection{Mineral Dissolution}

Apatite from Lao Cai factory, North Vietnam and Kaolinite mineral (commercial) were added to liquid Aleksandrov medium as the sole $\mathrm{P}$ and $\mathrm{K}$ source to test the ability of the isolates to solubilize these minerals and the isolates with the highest solubilization capacity were kept on Aleksandrov medium for further study.

Quantitative estimation of $\mathrm{P}$ and $\mathrm{K}$ solubilization was carried out in Falcon tubes $(50-\mathrm{mL})$ containing $30 \mathrm{ml}$ of Aleksandrov medium, and inoculated in triplicate with tested isolates $\left(1 \mathrm{ml}\right.$ inoculum with approximately $3 \times 10^{7}$ cfu ml-1). Autoclaved, uninoculated medium served as controls. The falcon tubes were incubated for 10 days on orbicutal shaker with $10 \mathrm{rev} \mathrm{min}^{-1}$ at temperature room. Samples were taken at two times: 5 and 10 day after incubation, $\mathrm{pH}$ value was measured with a $\mathrm{pH}$ meter, after that samples were centifuged at $8000 \mathrm{~g}$ for $10 \mathrm{~min}$. The supernatants were used to assay the solubilized $\mathrm{P}$ ( 5 and 10 day after incubation) and $\mathrm{K}$ (only at 10 day after incubation). $\mathrm{P}$ was estimated using the molybdo-vanadomethod (Oniani method) and $\mathrm{K}$ was examined using atomic absorption spectrometry[8]. Values are recorded and presented with average value for each sample, and differences were considered to be significant at the $\mathrm{P}<0.05$ level with LSD or Duncan test.

\subsection{Isolation of Bacteria}

Cultivation-based techniques were used to gain insight into the abundance and species composition of bacterial communities, and to reveal the poly-P accumulation of bacteria. Serial dilutions $\left(10^{-2}\right.$ to $\left.10^{-4}\right)$ of composite samples were prepared. Dilutions $(0.05 \mathrm{ml})$ were aseptically plated on the agar-based culture medium. Plates were incubated at $30^{\circ} \mathrm{C}$ for 5 days. Bacterial colonies were differentiated on the basis of colony morphology and pigmentation. Colonies were subculture on the agar-based subculture medium plates by striking technique and re-incubated at $30^{\circ} \mathrm{C}$ for 5 days. This isolation process carries out in shifts of the agar-based culture medium to the agar-based subculture medium until monocultures were obtained. Monocultures were culture on the agar-based culture medium slant in the test-tube $(12 \mathrm{ml})$ and incubated at $30^{\circ} \mathrm{C}$ for 4 days following by stored $10^{\circ} \mathrm{C}$ in refrigerator.

\subsection{Colony Characteristic and Microscopic Examination}

The characteristics of colony such as size, color, shape....were presented in each group, cell morphologies of the isolates were observed using an optical microscope and they were also observed on scanning electron microscope. 


\subsection{Phylogenetic Analysis of $16 S$ rRNA Gene Sequence}

Bacteria universal primers, the forward primer fD1 and the reverse primer $\mathrm{rP}[3]$ were used to amplified partial length of 16S rRNA gene sequence.

Genomic DNA was extracted from the cultures grown in Aleksandrov medium $30^{\circ} \mathrm{C}$ for $24 \mathrm{~h}[9]$. The $16 \mathrm{~S}$ rRNA gene sequence was amplified in a PCR mixture, composed with $1 \mu \mathrm{mol} 1-1$ of each primer. $200 \mu \mathrm{mol} 1-1$ of each dNTP, $50 \mathrm{mmol} \mathrm{l}^{-1} \mathrm{KCl}$ and $1.5 \mathrm{~mol} \mathrm{l}^{-1} \mathrm{MgCl}_{2}$ in $10 \mathrm{mmol} \mathrm{l}^{-1}$ Tris/ $\mathrm{HCl}(\mathrm{pH} 8.3)$ buffer. DNA $(0.1 \mu \mathrm{g})$ and $2.5 \mathrm{U}$ Taq DNA polymerase[Fermentas] were added in $100 \mu \mathrm{l}$ PCR mixture. PCR amplications were performed at $94^{\circ} \mathrm{C}$ for 5 min, 30 cycles of denaturation at $94^{\circ} \mathrm{C}$ for $1 \mathrm{~min}$, anneling at $55^{\circ} \mathrm{C}$ for $50 \mathrm{~s}$ and extension at $72^{\circ} \mathrm{C}$ for $105 \mathrm{~s}$; and a final extension at $72^{\circ} \mathrm{C}$ for $10 \mathrm{~min}$. Partial $16 \mathrm{~S}$ rRNA genes of some good bacterial strains was sequenced by MACROGEN, Republic of Korea (dna.macrogen.com) and they were chosen to sequence and the results were compared to sequences of GenBank based on partial $16 \mathrm{~S}$ rRNA sequence to show relationships between other P\&K-solubilizing bacterial strains $[10]$ and the phylogenetic analysis was constructed by the neighbour-joining method based on 1.000 bootstraps.

\section{Results and Discussion}

\subsection{Bacteria Isolation and Colony Characteristic}

From 10 soil samples/weathering materials, 25 isolates were isolated on Aleksandrov medium. They developed very well on this medium from $36-48 \mathrm{~h}$ at $30^{\circ} \mathrm{C}$, this showed that these isolates had $\mathrm{P}$ and $\mathrm{K}$-solubilizing capacity. Their colonies had round-shape, climy, smooth, colourless or milk-color, yellow and some colonies appeared to have much larger size (Figure 3). This result was the same Xiufang's experiment (2006) which was done at Tianmu Mountain, China however these colonies developed faster in Aleksandrov medium in 2 days instead of 4 days as Xiufang Xiufang's experiment at $30^{\circ} \mathrm{C}$.
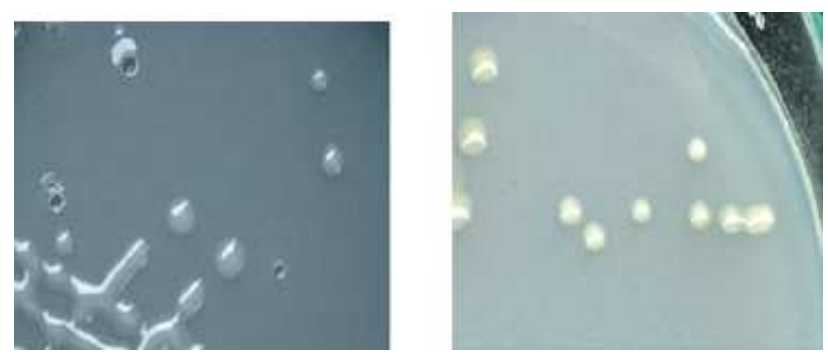

Figure 3. Characteristics of colonies of bacterial isolates after grown on Aleksandrov medium.

In the modified medium with apatite (Lao cai, Vietnam) and potassium mineral (kalolinite), the ability of the isolates to solubilized different $\mathrm{P}$ and $\mathrm{K}$ minerals was also investigated (Table 1).

All of 11 strains showed significantly higher solubilization of potassium mineral (kaolinite) than control and strain TC1A was the most efficient strain in solubilizing mineral $\mathrm{K}$ and this strain also had P-solubilizing ability after 10 days of incubation (Table 1). However K-solubilizing ability of all strains was higher than $\mathrm{P}$-solubilizing and $\mathrm{pH}$ values were measured at 5 and 10 day of incubation and the results showed that $\mathrm{pH}$ value were always higher than 6.5 perhaps they originate from denatured mountain at seaside (Thailand Bay).

Table 1. Phospate and potassium solubilization of 11 isolates

\begin{tabular}{cccc}
\hline $\begin{array}{c}\text { Name of } \\
\text { isolate }\end{array}$ & $\begin{array}{c}\text { Solubilization of } \\
\text { potassium } \\
\left(\mathrm{mg} \mathrm{K} \mathrm{l}^{-1}\right)\end{array}$ & \multicolumn{2}{c}{$\begin{array}{c}\text { Solubilization of phosphate } \\
\left(\mathrm{mg} \mathrm{PO}_{4}{ }^{3-1} \mathrm{1}^{-1}\right)\end{array}$} \\
\hline TC1D & $68.53 \mathrm{def}$ & 17.46 & $11.22 \mathrm{ef}$ \\
TC1B & $70.21 \mathrm{~d}$ & 5.11 & $12.01 \mathrm{de}$ \\
TĐ6A & $68.78 \mathrm{de}$ & 5.13 & $10.01 \mathrm{~g}$ \\
TĐ6B & $65.33 \mathrm{~g}$ & 5.27 & $15.24 \mathrm{e}$ \\
CH7D & $65.04 \mathrm{~g}$ & 8.52 & $10.42 \mathrm{fg}$ \\
CH7A & $70.33 \mathrm{~cd}$ & 9.82 & $19.01 \mathrm{~b}$ \\
CH9E & $72.56 \mathrm{bc}$ & 3.32 & $10.27 \mathrm{fg}$ \\
ĐNV16 & $67.27 \mathrm{efg}$ & 16.24 & $8.07 \mathrm{~h}$ \\
TC1A & $76.78 \mathrm{a}$ & 4.33 & $21.42 \mathrm{a}$ \\
TĐ13A & $62.57 \mathrm{~h}$ & 12.18 & $12.55 \mathrm{~d}$ \\
TĐ13B & $61.02 \mathrm{~h}$ & 4.19 & $10.14 \mathrm{~g}$ \\
Control & $0.69 \mathrm{j}$ & 1.77 & $2.01 \mathrm{k}$ \\
\hline
\end{tabular}

* days of incubation

** numbers following the same word not diffrence at $1 \%$ level

$\mathrm{P}$ solubilizing bacteria and silicate bacteria play an important role in plant nutrition through the increase in $\mathrm{P}$ and $\mathrm{K}$ uptake by the plant[3]. Application of Phosphate solubilizing microorganisms have been used as P-biofertilizer for crop cultivation[11][12]. Silcate bacteria provided less polluting and less energy-consuming approaches[13] widely used in improvement of available K for assimilation by plants, and removal of impurities from minerals[14]. As a strain effective in both P- and $\mathrm{K}$-solubilization, strain TC1A should have to potential to be applied as a $\mathrm{P}$ and $\mathrm{K}$ biofertilizer to increase $\mathrm{P}$ and $\mathrm{K}$ assimilation and crop yield simultaneously.

\subsection{Microscopic Examination}

Microscopic observations showed that the cells of bacterial isolates were motile, rod, Gram-positive and Gram-negative (Figure 4), short-rods $(0.8 \times 1.3 \mu \mathrm{m})$ and long-rods $(0.8 \times 1.7 \mu \mathrm{m})$.

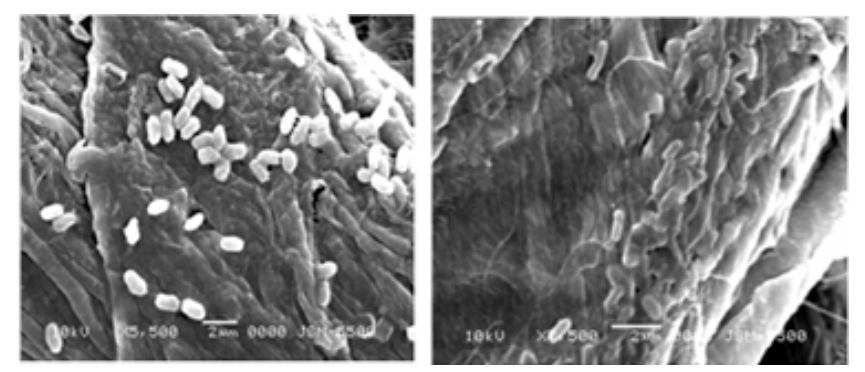

Figure 4. Electron microghaphs (bars, $2 \mu \mathrm{m}$ ) of cells of bacterial isolates grown on Aleksandrov medium 


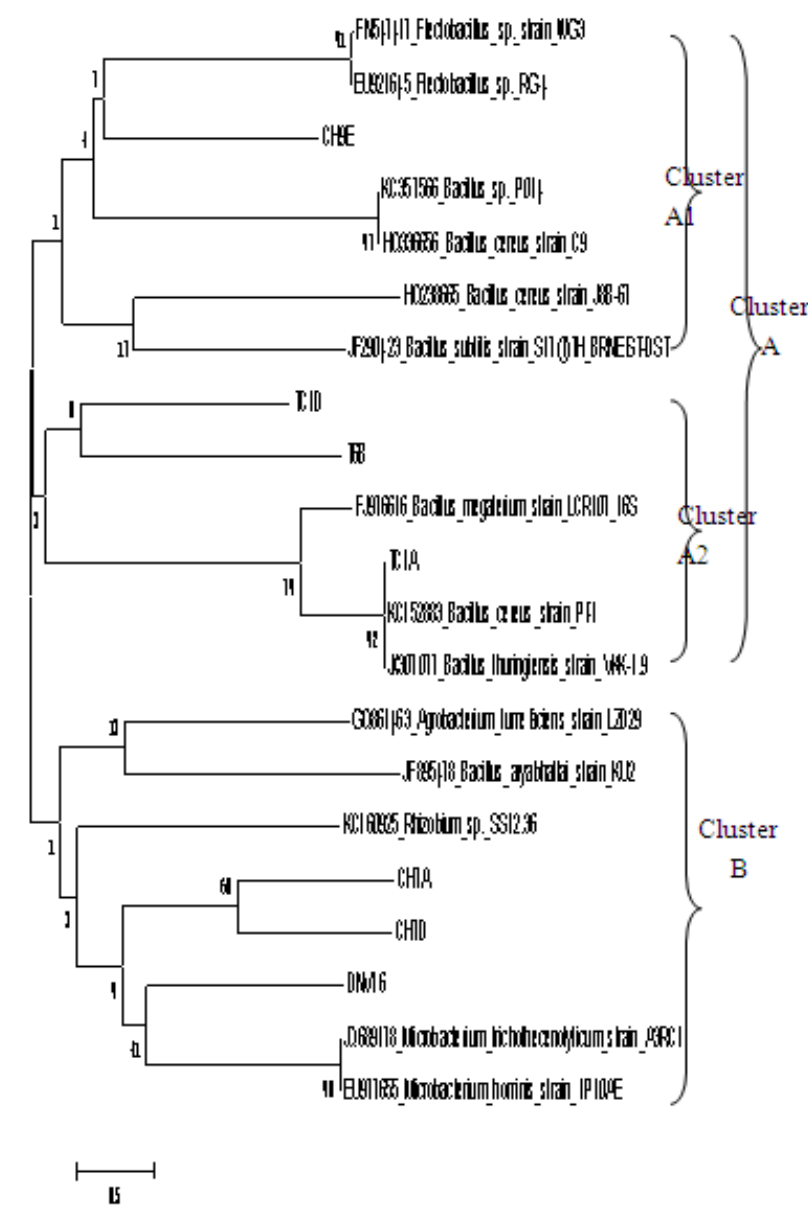

Figure 5. Phylogenetic tree showing the relative position of $P$-and $K$-solubilizing bacteria by the neighbor-joining method of complete $16 \mathrm{~S}$ rRNA sequences. Bootstrap values of 1000 replicates are shown at the nodes of the trees.

\subsection{Phylogenetic Analysis of $16 \mathrm{~S}$ rRNA Gene Sequence}

Bands of approximately $1500 \mathrm{bp}$ were obtained from the amplification of 16S rRNA gene sequence from 17 isolates among 25 isolates. With this result showed that 17 isolates were identified as $\mathrm{P}$ - and $\mathrm{K}$-solubilizing bacterial strains (CH7D, TĐ13C, ĐNV16, TĐ6A, CH7A, TC1B, TĐ6C, TC1C, BS8B, CH9E, TĐ12B, TĐ6B, TC1F, BS8C, TC1A, TĐ13A and TĐ13B) as Xiufang et al.'s experiment[3]. Simultaneous the similarities of seven isolates $(\mathrm{CH} 7 \mathrm{~A}$, TC1A, CH9E, CH7D, TC1D, ĐNV16 and TĐ6B) were 98 - 99\% with Microbacterium hominis, Flectobacillus sp., Bacillus cereus, Bacillus subtilis and Bacillus megaterium.

A neighbor-joining phylogenetic tree in $\mathrm{P}$ - and K-solubilizing bacteria showing 2 clusters: cluster A with two cluster A1 and A2 among cluster A1 Flectobacillus sp. with $\mathrm{CH} 9 \mathrm{E}$ isolate and cluster A2 Bacillus megaterium with TC1D, T6B and TC1A isolates. Cluster B Microbacterium hominis with three isolates: CH7A, CH7D and DNV16. The results showed that $\mathrm{P}$ - and K-solubilizing bacteria mainly are genus Bacillus.

About of $75 \%$ of the world's coastlien is roch cliff[15]; denatured rock at Ha Tien mountain, Kien Giang province, Vietnam originates from calcite-sedimentary rock but it had been formed from seism with low level. The denatured rock has been formed by mud-rocks and shales and the weathering of mud-rocks and shales, fine-grained sedimentary rocks made from clay minerals of important environmental processes, especially shales contain clays thet are the products of silicate weathering prior to rock formation.

Microorganisms are known to mediate rock weathering[16][17][18] and Cocktell et al.[2] demonstrated that the physical and chemical micro-environment of weathered shales of coastline cliffs in the northwest of England was Proteobacteria, with phylotypes closely associating with Methylocella and other members of the $\gamma$-subdivision. Our results showed that the baterial strains closely related with Bacillus perhaps these bacterial strains developed with the presence of plants, the results of this study also determined the our experiment which was done on weathered materials of calcacerous mountain, Kiên Giang, Vietnam[19].

\section{Conclusions}

From soils or weathering materials of denatured mountain, Ha Tien, Kien Giang, Vietnam appeared many bacterial strains which solubilized phosphate and potassium minerals. Strain TC1A exhibited higher solubilization of Phosphate and Potassium in comparison to all strains and it will be used to produce biofertilizer in the future.

\section{Acknowledgements}

The author thanks the helpness of Biotechnology MSc. students and technicians in the Environment Microbiology Laboratory, Biotechnology R\&D Institute, Can Tho University, Vietnam.

\section{References}

[1] A.H. Goldstein, Involvement of the quinoprotein glucose dehydrogenase in the solubilization of exogenous phosphate by gram-negative bacteria. In: Torriani-Gorini, A., E. Yagil, S. Silver. Phosphate in Microorganisms: Cellular and Molecular Biology. Washington, DC. ASM Press, 1994, pp.197 - 203.

[2] C.S.Cockell, D. Pybus, K. Olsson-Francis, L. Kelly, D. Petley, N. Rosser, K. Howard, and F. Mosselmans, Molecular Characterization and Geological Microenvironment of a Microbial Community Inhabiting Weathering Receding Shale Cliffs, Microb. Ecol. vol (61), 2011, pp. 166-181.

[3] H. Xiufang, C. Jishuang and G. Jiangfeng, Two phosphateand potassium- solubilizing bacteria isolated from Tianmu Moutain, Zhejiang, China. World Journal of Microbiology and Biotechnology. vol (22), 2006, pp. 983 - 990.

[4] N.V. Thanh, V.T.Xuan, L.Q.Tri and V.Q.Minh, Studies on main crop systems cultivated on sulfaquept soils in Mekong Delta. MSc. Thesis, Can Tho University, Vietnam. 1997 
[5] J.I. Sperberg, The incidence of apatite- solubilizing organisms in the rhizosphere and soil. Australian Journal of Agricultural and Resource Economics vol (9), 1958, p.778.

[6] A.H. Goldstein, Bacterial solubilization of mineral phosphates: historical perspective and furture prospects. American Journal of Alternative Agriculture1, 1986, pp.5157.

[7] V.G. Aleksandrov, R.N. Blagodyr and I.P. Ilev, Liberation of phosphoric aicd from apatite by silicate bacteria. Mikrobiolohichnyi Zhurnal (Kiev) vol(29), 1967, pp.111 114.

[8] M. Manib, M.K. Zahra, A.L. Abdel, and A. Heggo, Role of solicate bacteria in releasing $\mathrm{K}$ and $\mathrm{Si}$ from biotite and orthoclase. In. Soil biology and Conservation of the Biosphere, ed. Szegi J. 1986, pp.733-743. Budapest, Akademiai Kiado, ISBN 9630537001.

[9] B. Neumann, A. Pospiech and H.U. Schairrer, Rapid isolation of genomic DNA from Gram - negative bacteria. Trends Genet, vol (8), 1992, pp.332 - 333.

[10] K. Tamura, D. Peterson, N. Peterson, G. Stecher, M. Nei and S. Kumar, "MEGA5: Molecular Evolutionary Genetics Analysis Using Maximum Likelihood, Evolutionary Distance, and Maximum Parsimony Methods," Mol. Biol., vol. 28(10), 2011, pp. 2731-2739.

[11] M. Datta, S. Banish, and R.K. Dupta, Studies on the efficiency of a phytohormone producing phosphate solubilizing Bacillus firmus in augmenting paddy yield in acid soils of Nagaland. Plant and Soil vol (69), 1982, pp.365-373.

[12] C. N. Diep, T. T. Phong and T. T. Giang, Isolation and Selection of phosphate-solubilizing and IAA-biosynthesis Pseudomonas sp. Science and technology J. Agriculture and
Rural Development. Ministry of Agriculture and Rural Development, Vietnam vol (9), 2009, pp.32-35.

[13] Z.A. Burgstaller, H. Sreasser, H. Wobking and F. Shinner, Solubilization of zinc oxide from filterdust with Penicillium simplicassimum bioreactor, leaching and stoichiometry. Environmental Science and Technology vol (26), 1992, pp.340-346.

[14] G.G. Nianikova, E.E. Kuprina, O.V. Pestova, and S.V. Vodolazhskaia, Immobilizing of Bacillus mucilaginosus, a producer of exopolysaccharides, on chitin. Priklalmaia Biokhilia I Mikrobiologiya vol (38), 2002, pp. 300-304.

[15] E. Bird, Coastal geomorphology: an introduction, John Wiley and Sons, Incs, New York, 2000.

[16] S.A. Welch, W.W. Barker, and J.F. Banfield, Microbial extracellular polysaccharides and plagioclase dissolution. Geochim Cosmochim. Acta. vol (63), 1999, pp.1405-1419.

[17] P.C. Bennett, J.R. Rogers, W.J. Choi, and F.K. Hiebert, Silicates, silicate weathering, and microbial ecology. Geomicrobiol. J. vol (18), 2001, pp.3-19.

[18] K.R. Glowa, J.M. Arocena, and H.B. Massicotte, Extraction of potassium and/or magnesium from selected soil minerals by Piloderma. Geomicrobiol. J., vol (20), 2003, pp. 99-111.

[19] C.N. Diep, N.T. Don, T.T.H. Nhung, and L.T.D. Thanh, Isolation and identification of phosphate- and potassium-solubilizing bacteria in weathered materilas from calcacerous mountain, Kien Giang, Vietnam. Proceeding of the 2012 International Symposium on Biology Science and Environmental Engineering (ISBSEE 2012) organized at Chinam, Malaysia from 28-30 $0^{\text {th }}, 2012$. 